\title{
NOTE
}

This is a pre-final version. The published version can be found in:

https://www.tandfonline.com/doi/full/10.1080/02666030.2018.1440056

MACHADO, Everton V. (2018) - «Hyperidentity and Orientalism: the case of the

Sieges of Diu in Portuguese texts». In South Asian Studies. 34 (1): 6-16.

\section{Hyperidentity and Orientalism: The Case of the Sieges of Diu in Portuguese Texts ${ }^{1}$}

Everton V. Machado

Centro de Estudos Comparatistas, University of Lisbon

The Portuguese representations of the sieges of Diu have been produced over the span of five centuries. My main argument is that, in these texts, Diu served as a pretext to reaffirm the glories of Portugal in Asia during the 16th century, as well as to establish an ontological and epistemological distinction between the West and the East. Such representations stem from what Eduardo Lourenço calls 'Portuguese hyperidentity', a notion which helps us understand how the discourses about Diu articulate knowledge and power. The relevance of establishing a connection between Edward W. Said's theory of Orientalism and Lourenço's viewpoint lies in the fact that both the 'Western conceptions of the Orient' and the affirmation of Portuguese identity and belonging participate of what Michel Foucault called 'regime of truth'.

Keywords: Diu; hyperidentity; Islam; knowledge and power; Orientalism; Portugal

The Portuguese representations of the sieges of Diu (the first of which took place in 1538, and the second in 1546) have been produced over the span of five centuries. Through the invariant characteristics of those representations, we will attempt to understand Portugal's 'contribution' to Orientalism - which Edward W. Said himself suggested in Orientalism: Western Conceptions of the Orient ${ }^{2}-$, since, as will be shown, they clearly integrate what the author calls 'a distribution of geopolitical awareness into aesthetic, scholarly, economic, sociological, historical, and philological texts' capable of creating and maintaining 'a basic geographical distinction' between the Occident and the Orient, as well as a series of 'interests' ${ }^{3}$ (whether of a political, 
cultural, economic, religious or military nature) underlying that distinction. A significant corpus of Portuguese texts predate the period that Said considered (from the $18^{\text {th }}$ century onwards) within the scope of Modern Orientalism and in a geopolitical context from which Portugal is absent. However, texts such as Luís Vaz de Camões' The Lusiads, published in the $16^{\text {th }}$ century, or Arthur Lambert da Fonseca's $O I I^{\circ}$ Cerco de Diu ['The Second Siege of Diu'], from the $20^{\text {th }}$ century, confirm the notion of the 'durability' and 'strength'4 that the cultural hegemony of the Occident bestows on Orientalism. ${ }^{5}$

To justify my approach to the problem and my conclusions, I make use of the methodological devices Said used to study the 'authority' of the Occident over the Orient:

[...] strategic location, which is a way of describing the author's position in a text with regard to the Oriental material he writes about, and strategic formation, which is a way of analyzing the relationship between texts and the way in which groups of texts, types of texts, even textual genres, acquire mass, density, and referential power among themselves and thereafter in the culture at large. I use the notion of strategy simply to identify the problem every writer on the Orient has faced: how to get hold of it, how to approach it, how not to be defeated or overwhelmed by its sublimity, its scope, its awful dimensions. Everyone who writes about the Orient must locate himself vis-a-vis the Orient; translated into his text, this location includes the kind of narrative voice he adopts, the type of structure he builds, the kinds of images, themes, motifs that circulate in his text - all of which add up to deliberate ways of addressing the reader, containing the Orient, and finally, representing it or speaking in its behalf. ${ }^{6}$

The hermeneutic exercise aimed at here points to the fact that the Portuguese representations of the sieges of Diu stem from what the contemporary Portuguese philosopher Eduardo Lourenço calls 'Portuguese hyperidentity'. It can be defined as a series of images produced by Portugal about itself, always revealing an obsession with the "Camonian" titles of our planetary vocation from the 16th century"7. Luís Vaz de Camões (c. 1524 - c. 1580), who lived for almost fifteen years in the Orient and holds the highest honour in Portuguese culture, wrote the famous epic poem The Lusiads (1572). Lourenço defines it as the 'première épopée européenne', the one that invented the 'regard européen en tant que regard planetaire,8. The Lusiads narrates Vasco da Gama's (1469-1524) famous discovery of the maritime route to India (1497-98), within 
the context of the struggle to control commerce in the Mediterranean and fight against Islam.

With regard to the texts that will be mentioned, my main argument is that Diu served mainly as a pretext to reaffirm the glories of Portugal in Asia during the 16th century revealing a clear desire for Portugal to maintain the role it had there in that period, in other words, its power -, as well as to establish 'an ontological and epistemological distinction made between "the Orient" and (most of the time) "the Occident" "9. In fact, Said does not mention Portugal more than four or five times, and rather briefly at that. Starting off, essentially, with the Foucauldian notion of discourse (which presupposes an articulation between knowledge and power) and the concept of hegemony of Antonio Gramsci, ${ }^{10}$ Said dedicates his study to England and France, seeking to demonstrate how, after those nations emerged as colonial powers at the end of the $18^{\text {th }}$ century, an entire corpus of knowledge concerning the Other was constituted (stimulated by the epistemological turn of the Enlightenment and consequent disciplinarization of knowledge), aimed at the domination of that Other. ${ }^{11}$ It should be noted that I will deal with texts still conditioned by a religious vision of the world. Therefore, they predate the aforementioned turn, which would, in fact, consolidate the differences between the Occident and the Orient in terms of the imaginary and the sciences. But it should also be noted that Said himself draws attention to the fact that there was a 'secularizing tendency, this is not to say that the old religious patterns of human history and destiny and "the existential paradigms" were simply removed. Far from it: they were reconstituted, redeployed, redistributed in [...] secular frameworks' ${ }^{12}$ These questions are important to problematize Portuguese Orientalism, since, for many specialists, it would be difficult to apply the patterns indicated by Said to the case of Portugal, given the multifaceted nature of the Portuguese Empire (which did not have a defined practice as a regular or continuous political project $)^{13}$, or the fact that the most significant part of the Portuguese cultural production concerning the Orient was created in the context of a Respublica Christiana. ${ }^{14}$

I should further explain that the current analysis deals with the method of Said, in the domain of Comparative Literature. As Robert J. C. Young wrote about Orientalism, 'Said demonstrated the uniformity of attitudes, imagery, and stereotypes across various types of discourse, and it was this extraordinary scope of the book which was so important from a comparativist point of view'. Significantly, 'he did not, therefore, so much compare different texts from different languages and disciplines per se as show 
the consistency of the discursive perspective that can be discerned across them' ${ }^{15}$ Regarding the texts on Diu studied here, there are differences among all (with respect to the locus of enunciation, genre, development of action, context of historical production, etc.), but my main focus is to verify the hypothesis proposed by Said whereby 'both learned and imaginative writing are never free, but are limited in their imagery, assumptions, and intentions, ${ }^{16}$ making the Orient appear to us 'as a phenomenon possessing regular characteristics' ${ }^{17}$

\section{Morbid fixation with the contemplation of difference}

My starting point is that the aforementioned 'phenomenon', in the Portuguese case, cannot be greatly appreciated without the imagery that Portugal came to produce about itself over time, through various types of individual discourses and with different immediate objectives, but simultaneously configuring 'the dialectic between individual text or writer and the complex collective formation to which his work is a contribution'. ${ }^{18}$ Such imagery certainly has an impact on the perception that individuals have of themselves as members of a collectivity, and in how they relate with the members of another collectivity. As Said stresses:

\footnotetext{
if it is true that no production of knowledge in the human sciences can ever ignore or disclaim its author's involvement as a human subject in his own circumstances, then it must also be true that for a European or American studying the Orient there can be no disclaiming the main circumstances of his actuality: that he comes up against the Orient as a European or American first, as an individual second. And to be a European or an American in such a situation is by no means an inert fact. It meant and means being aware, however dimly, that one belongs to a power with definite interests in the Orient, and more important, that one belongs to a part of the earth with a definite history of involvement in the Orient almost since the time of Homer. ${ }^{19}$
}

The Portuguese are no exception to the rule: not only did they have very specific interests in Asia, but they could also only engage with the Orient as Portuguese, an identity that is, in fact, still strongly shaped by the very effects of that engagement. Eduardo Lourenço's notion of Portuguese hyperidentity guides us precisely through these effects. 
In Lourenço's most famous work, O Labirinto da Saudade - Psicanálise Mítica do Destino Português ['The Labyrinth of Saudade - Mythical Psychoanalysis of the Portuguese Destiny'], originally published in 1978, he speaks of the 'supernumerary vertebra' which make the Portuguese 'always live beyond our means' and 'without national identity problems per se', as well as their own self-reflective 'hyperbolic image of the former lords of "Conquest", "Navigation", "Ethiopia", etc.' ${ }^{20}$ In this book, Lourenço proposes an exercise in imagology, which is 'a critical discourse on the images that we ourselves have forged'. ${ }^{21}$ In a 1983 essay, Lourenço speaks again of a 'nation without identity problems', and actually uses the term hyperidentity for the first time. ${ }^{22}$ In an earlier essay from 1975 , he had resorted to the term 'hypernationalism'; in 1987, in a newspaper article, he uses 'superidentity' in addition to hyperidentity. ${ }^{23}$ In Nós e a Europa ou as duas razões ["We and Europe or the Two Reasons"] (1988), he gives us a summarized definition of hyperidentity by stating that the problem of the Portuguese would not be 'a problem of identity, [...] but of hyperidentity, of an almost morbid fixation with the contemplation and delight in the difference that characterizes us or that we imagine in the context of other peoples, nations and cultures' ${ }^{24}$ This hyperidentity would characterize Portugal 'at least since the 16th century', ${ }^{25}$ having founded its 'archetypal grandeur' on the self-perceived role of colonizing nation 'par excellence and of which glory The Lusiads are the door and whole temple'. ${ }^{26}$ Portugal's position in Europe's internal power game became tributary to this self-perception, not to mention that it has always been a principal constituent of that self-perception because of the country's peripheral position in relation to other European forces. In summary, hyperidentity is no more than 'our double identity as a non-hegemonic European people and as a people'. ${ }^{27}$

The 'excess of identity' that the hyper- and supra- prefixes reference is explained through two ambiguities, the first of which is common to all peoples: 'to the divergence between the "ideal being" and "real being" of a people is added among us, especially due to The Lusiads, the pathological mismatch between present and past, in which we are only truly who we are, but we know how to be because we have already been so one day'. ${ }^{28}$ What had motivated Camões in The Lusiads was an 'amazed conscience of the disproportion between the "small Lusitanian house" and the open seas', the problem of that epic being that 'the reality of the European cultural conscience from that period did not allow it'; The Lusiads 'are not so much the expression of a real epic as the conscience of an epic that could only develop with such 
splendour and the necessary naiveté due to the grandiose disproportion between agent and action'. ${ }^{29}$ Thus, Camões authorized the 'cultural fixation with the 16th century', prolonging a "nostalgia all the more profound as it is certain that the national existence as a whole could never again find a similar historical moment' ${ }^{30}$

The fact is that the political events of the 19th century - the flight of the Portuguese royal family because of Napoleon's invasion in 1808, the loss of Brazil in 1822, the reinforcement of the economic dependence on England, the imposition of a new colonial model (associated with economic, scientific and technological development) - will undermine the 'archetypal grandeur' of Portugal as a 'colonizing nation 'par excellence'. This gave way to a true 'image problem', ${ }^{31}$ substantiated in the previously mentioned mismatches, which affected the monarchy as well as, in the 20th century, the Republic and the Estado Novo (Antonio de Oliveira Salazar's dictatorial regime, 1933-1974). The emergence of the 'general norm, 32 that British colonialism came to represent became Portugal's Achilles' heel: it did not fit the requirement of an effective occupation of the conquered territories and was targeted by countries involved in the race for Africa; it insisted on the possession of a territorial strip between Angola and Mozambique, claiming historical rights, but ended up ceding territory to England after an ultimatum in 1890. As Lourenço writes:

Up until the 19th century - when a Europe in the midst of economic, political and social revolution enters our home, militarily with the Napoleonic invasion and ideologically with the liberal model -, only an elite, generally with a cosmopolitan experience, was sensitive to the image of Portugal in the mirror of others, or in the gaze of others. Without a concrete standard of comparison, the relation of the Portuguese with themselves was indifferent to the inferiority complex that little by little permeated the Portuguese social elite from the $19^{\text {th }}$ century and culminated in the public reassessment of the Portuguese past or decisive components of its profile [...]. The conscience of our peripherality, spurred by the romantic memory of the $16^{\text {th }}$ century and our role in that period, reached its most painful level. Europe is at the same time the model to imitate and our despair, given the distance that separates us from it. Not even the fact that our small country still belonged to the number of nations with a potentially rich colonial space rebalanced the mediocre image, the collective feeling of our little worth among the new hegemonic nations of the Occident. One of them, the very one that had been an old ally, and to whom we had ties of economic interdependence, though mostly of dependence - would give us an 
ultimatum in 1890 that would reduce our imaginary dimension of colonizing nation to its most minute proportion. Neither in Europe nor outside of it were we a people of importance or whom it was necessary to take into account. An entire literature echoed this painful and pessimistic experience of a present without a future, or invested in the invention of compensatory myths for our frustration of an ancient glorious people $[\ldots]^{33}$

Eduardo Lourenço's notion, which problematizes what he himself calls 'our image as a product and reflection of our existence and our historical project throughout the centuries ${ }^{34}$ in the framework of the Philosophy of History and Culture Studies, could work as a concept to approach Portuguese Orientalism from the $16^{\text {th }}$ to the $20^{\text {th }}$ century, as it reveals a structured and persistent pursuit of difference. The Eastern - not to say the "Rest" from "The West and the Rest" he who expects to retrieve his image in the mirror of Europe. As Said writes:

The central point in all this is [...], as Vico taught us, that human history is made by human beings. Since the struggle for control over territory is part of that history, so too is the struggle over historical and social meaning. The task for the critical scholar is not to separate one struggle from another, but to connect them, despite the contrast between the overpowering materiality of the former and the apparent otherworldly refinements of the latter. My way of doing this has been to show that the development and maintenance of every culture require the existence of another different and competing alter ego. The construction of identity - for identity, whether of Orient or Occident, France or Britain, while obviously a repository of distinct collective experiences, is finally a construction - involves establishing opposites and "others" whose actuality is always subject to the continuous interpretation and reinterpretation of their differences from "us". Each age and society recreates its "Others". Far from a static thing then, identity of self or of "other" is a much worked-over historical, social, intellectual, and political process that takes place as a contest involving individuals and institutions in all societies. $^{36}$

In that sense, by analyzing the knowledge produced or disseminated about the oriental Other, the notion of hyperidentity allows us to duly locate the various discourses, through the identification of their ideological assumptions, in the projections and reaffirmations of the idea of a Portuguese Empire. This will therefore prevent the depletion of the power dimension inherent to the discourses. As Rosa Maria Perez 
reminds us, Said sees Orientalism as a discourse, one which will be Orientalist (in literature, historiography, anthropology, visual arts) when the desire for knowledge is tied in with the desire for power. ${ }^{37}$ And what is hyperidentity if not a series of discourses founded on the idea of a 'discovering and colonizing enterprise', as Lourenço writes, 'identified as the fundamental activity of the Portuguese Nation'? ${ }^{38}$ The relevance of establishing a connection between Said's theory and Lourenço's notion lies in the fact that both the 'Western conceptions of the Orient' and the affirmation of Portuguese identity and belonging participate of what Michel Foucault called 'regime of truth', which 'induces regular effects of power' ${ }^{39}$ The very idea of 'Nation', according to Patrik Hall, implies 'the social relation of power and knowledge [...] where the nation appears to be the historical subject', ${ }^{40}$ and the conquest of the East by the Lusitanians is one of the most significant elements of the discourses about Portuguese identity constructed over time.

There may be a divergence between the image of grandeur that Portugal has of itself and what it is capable of gaining in the geopolitical reality when confronted with world powers that were able to do it better (according to a new standard of empire) that which Lourenço calls 'hypertrophy of the national conscience"41 - , but the fact is that Portugal was not only the first one to enter the expansionist adventure of modern Europe along with Spain, but it was also the last one to leave: it left India in 1961, Africa only in the 1970s, and Macau at the end of the 20th century. Stating that there was no 'authentic colonization, if we understand by that an enterprise of the entire Nation, concerted and undertaken with method and continuity' does not mean that the colonial action changed its meaning: 'its essence is that of the subordination of the historical, economic, social and cultural reality of the colonized'. ${ }^{2}$ The issue here is to verify whether the knowledge generated by the Portuguese concerning the Orient 1) allowed the Orient to help define Portugal 'as its contrasting image, idea, personality, experience, ${ }^{43}$ 2) established an ontological and epistemological distinction between one and the another, and 3) contributed to legitimize practices of power, that is, as in the equation between Orient and Europe/Occident proposed by Said. The current debate about Portuguese Orientalism often insists on its specificity with regard to the British and French contexts, ${ }^{44}$ in a way that risks being mistaken for the myth of the exceptionality of Portuguese colonialism. Lourenço writes of this myth that 'its distinctive characteristic is that of affirming an other-colonization and, in the long run, 
of conceiving it as a "never-ending portugalization" of the territories and peoples that History has placed in our path'. ${ }^{45}$

\section{Diu's 'Inexpugnable Wall' versus the 'Orient'}

The sieges of Diu occurred in the context of the fight of Christendom against Islam. The political-expansionist project of King Manuel I (1469-1521), who was behind the discovery of the sea route to India, did not have the sole objective of finding an alternative route for the commerce of silk and spices, which until then was made only via the Mediterranean; the sovereign of Portugal still (or mostly) expected to take control of Jerusalem. ${ }^{46}$ It should also be noted that Portugal is a 'country born out of the Holy War', ${ }^{47}$ with the Muslims being completely expelled from the territory in the $13^{\text {th }}$ century.

Twelve years after the arrival of Vasco da Gama to Calicut (1498), Afonso de Albuquerque conquered Goa, which would become the seat of the Estado Português da Índia, originally established in Cochin. Shortly thereafter, the Portuguese began exerting pressure on the sultanate of Gujarat to establish a trading post in Diu, through attacks and a maritime blockade; as a result of the weak position of the sultanate in the fight against the Mughals, the sultan Bahadur Shah sought an alliance with the Portuguese, and allowed their settlement in the territory (1535). However, 'based on the eventual regret of sultan Bahadur, who had allegedly convinced some rulers from the Malabar to expel the Portuguese, in 1537 the governor Nuno da Cunha encouraged his assassination, which triggered a war of indignation against the Portuguese' ${ }^{48}$ The Muslims then laid two sieges, one in 1538 and another in 1546 - two frustrated attempts at regaining the territory which came to be celebrated as one of the great demonstrations of the force and authority of the Portuguese Empire. As Maria Teresa Amado states: 'the value of Diu resided in its excellent strategic location, which allowed it to control navigation and commerce to the Red Sea and Persian Gulf', and, following the two sieges, 'a powerful defense system was built in Diu that still causes admiration today because of its scale" 49 , although the fortification of the place had already begun when it was first ceded. At the time of the first siege, captain António da Silveira stands out as the conductor of the Portuguese resistance. As for the second siege, two names stand out: that of the governor of Diu, D. João de Mascarenhas, and that of the governor- 
general of Portuguese India, D. João de Castro, who was appointed Viceroy of the Estado as a result of his victory there.

Both the 'inexpugnable' fortress - a qualifying adjective that I borrow from Camões' description of Diu (see below) - as well as the military feats of the heroic Portuguese will become the main topoi in Portuguese narratives of the sieges: ${ }^{50}$ the actions associated with those events will be overstated as a way of trying to assert the might of the Portuguese Empire. Commenting on Damião de Góis' depictions of the two sieges in two Latin opuscula (1539 and 1549), Jorge A. Osório says that 'by circulating accounts of this type in the cultured and universal language of Europe, Góis contributed to another function of Portuguese propaganda: to demonstrate that the Portuguese possessed not only the courage but also the strategic knowledge necessary in wars characterized by sieges of fortified towns such as Diu'. ${ }^{51}$

Recent studies have explored the historiographic representations of the sieges, within the domains of political and military history and of architectural and urban history. Nuno Grancho's conclusion is in line with my analysis:

Shifts in its meaning and significance over time, narrative connections to images of architecture, and the politicized marking of the historical site, all contribute to the ambiguous, miscellaneous role of the sieges in the architectural and urban histories of the city. The echoes of the events across the sixteenth until the nineteenth century, transformed seemingly similar and singular events into one which continued to affect colonial discourse well into the twenty first century. ${ }^{52}$

Equally important for my argument - the narrative construction of Portugal's 'archetypal grandeur' articulating knowledge and power - is the conclusion of Roger Lee de Jesus about the second siege (the most depicted one), which, furthermore, indicates the wide deficit between the ideal and real that is present in Portuguese hyperidentity:

[...] the second siege of Diu constitutes a common and almost 'banal' type of operation in the context of Modern European Military History [...]. What makes it unique is the fact that it takes place in a peripheral place, involving opponents that are quite different, both in terms of strategic and logistic planning, and of military technological investment. Despite the existing unevenness, the Portuguese fought against an Indian power that strongly rivalled in the domain of the land, thus counterbalancing the Portuguese control of the seas. The fact that it opposed such distinct political, social and 
economic realities reinforces the interest in analyzing this assault and demonstrates the Portuguese (and, in part, Gujarati) flexibility to adapt to the available means of warfare. Concerning the victory in the siege, D. João de Castro guaranteed to King João III that '[...] there will always remain a memory of it in these parts [of the Orient]'. If the memory of the siege has dissipated in those places, its image has become engraved in the imaginary of Portuguese Expansion in Asia, along with the certainty that the besieged and the besiegers defended there their values, beliefs and desire for supremacy in a world undergoing a profound change. ${ }^{53}$

Although reports, private letters and official documents had already dealt with these military events and had circulated before the publication of The Lusiads in 1572, it would not be wrong to say that, because of the "role of the Poem in the history of national conscience', ${ }^{54}$ it was the work of Camões that crystalized the canonical representation of the myth of the sieges of Diu. This poem constitutes, moreover, the canonical representation of the very myth of Portugal. As Manuel Cândido Pimentel writes:

The constellation of values that exist in historical myths, which coincide with the truth they express or wish to express, adapts and combines in the direct reencounter with the circumstances of history itself, because the myths speak of that part which is always conserved in them, the cultural identity of a community. If they die and incomprehensibly resurrect, it is because of that identity, which is neither timeless nor even transversal to time, but an agent of time and memory that conserves the past and limits the future. ${ }^{55}$

However, it is necessary to emphasize that, in the construction of that cultural identity of the Portuguese community, as stated by Margarida Calafate Ribeiro:

[...] by enabling the encounter with the 'Other', the Discoveries, in their European elaboration, enabled the definition of Europe as the center of identity, power and cultural irradiation in relation to that 'Other', whom the Europeans interpreted, imagined and constructed in successive metaphors of contrast, according to the times and respective politics of difference $[\ldots] .{ }^{56}$ 
The Camonian imagination offers the reader of The Lusiads a depiction of the Muslims that was already fairly trivial at the time, but it is interesting to note how, when it comes to the representation of the sieges, this contrast is established not so much through the use of comparative adjectives but rather through the constant use of superlatives to describe Portuguese warfare against the enemies - it is the grandeur of the feats of arms that serves as an identity boundary between the (hyper-)Self and the Other. Let us look at an example from Canto II (stanza 50) and another one from Canto X (stanza 68), in which the actions of the Lusitanians are prophesized:

\footnotetext{
Shalt see of Diu th'inexpugnable wall

two sieges braving, while thy sons defend;

there shall their val'orous worth be shown to all,

with feats of arms that every feat transcend:

envy shalt see in Mars majestical

of Lusian fierceness none shall dare offend

There shall they sight the Moor with voice supreme

before High Heaven false Mahound blaspheme. ${ }^{57}$

The fightful Perse, th'Abassian and the Rume,

who hath revived the name of Rome, their liege,

of varied customs, various in costume,

fell tribes a thousand flocking to the siege;

on Earth against the Heav'ens shall vainly fume

that gars such handful so their lands abridge:

In blood of Portingalls this Paynimry,

voweth its crookt and curved moustache to dye. ${ }^{58}$
}

If there is an affirmation of Portuguese power here, it exists only inasmuch as it functions within the dynamics created by a boundary between the (customs of the) Orientals and the (customs of the) Occidentals. A boundary made very clear in the poem through the idea of "inexpugnable wall" in Canto II, which immediately suggests the topos of the fortress. The fortress of Diu is nominally referred in stanza 64 of Canto X, as are, within the description of the sieges of Diu, those of Chale, Bassein and Daman. This boundary is not so much physical as it is ontological, since the historical events acquire their relevance in articulation with the danger permanently embodied by the 
'false Mahound'. There, the image of Mohamed represents the Orientals themselves. As Ziauddin Sardar explains, the idea that Mohamed was 'false' (in contrast with Jesus) is part of the medieval perceptions and attitudes conserved by the Europeans of the Reformation and Counter-Reformation, a period in which the modern concepts of the Occident were formulated. ${ }^{59}$ On the other hand, as Said says when speaking of Barthélemy d'Herbelot's Bibliothèque orientale ( $17^{\text {th }}$ century):

\begin{abstract}
Such "images" of the Orient as this are images in that they represent or stand for a very large entity, otherwise impossibly diffuse, which they enable one to grasp or see. They are also characters, related to such types as the braggarts, misers, or gluttons produced by Theophrastus, La Bruyère, or Selden. Perhaps it is not exactly correct to say that one sees such characters as the miles gloriosus or Mahomet the imposter, since the discursive confinement of a character is supposed at best to let one apprehend a generic type without difficulty or ambiguity. D'Herbelot's character of Mahomet is an image, however, because the false prophet is part of a general theatrical representation called orientale whose totality is contained in the Bibliothèque. ${ }^{60}$
\end{abstract}

If we focus our attention on other writings about the sieges of Diu, such as Lopo de Sousa Coutinho's História do Cerco de Dio ['History of the Siege of Diu'] (1556), by Jerónimo Corte-Real's Sucesso do segundo cerco de Diu ['Success of the Second Siege of Diu'] (1574), Francisco de Andrade's O primeiro cerco que os turcos puseram à fortaleza de Diu nas partes da Índia [The first siege that the Turks laid on the fortress of Diu in the parts of India'] (1589), and Simão Machado's Comédia de Diu ['Comedy of Diu'] (1601), we can observe the same mental construction operated by Camões, with the hyperbolization of Portuguese feats (from which we cannot dissociate the heroification of the participants in the sieges) through which the 'Moor', the 'Turk' or the 'Mahound' appear less as enemies than as synecdochical images of the Orientals.

Fernando Machado Silva has noted the role played by the topos of the 'Old Moor' (a kind of teratological monster of Renaissance culture) in the narratives of Sousa Coutinho, Francisco de Andrade and Simão Machado: "within the field of signification borne by the monster, this Moor [...] carries with him the signs of a historical weight (customs, traditions, etc.) which must be endured by the Portuguese in the course of their occupation of Eastern lands' ${ }^{61}$ In Jerónimo Corte-Real's work, the fact that the Moors are portrayed in a better light on the battlefield - 'brave, 
hardworking, strong Moors' (stanza 5) - does not prevent, as Hélio J.S. Alves points out, 'Corte-Real's conviction of the falsehood and evil nature of the Koran' ${ }^{62}$

With the exception of the first account (which is by a participant in the first siege, Sousa Coutinho), these narratives make use of the gods of Greco-Roman mythology as well as classical rhetorical resources, which was common in the Portuguese literature of the time and has been widely studied in the domain of Literary Studies. However, the historians Ângela Barreto Xavier and Ines G. Zupanov offer a new perspective on its occurrence in Renaissance Portugal:

In addition to this kind of dialogue with antiquity, the Portuguese turn towards antiquity was also a movement towards primitive Christianity, very much influenced, at a certain moment, by the reception of Erasmian Christian humanism. This meant that the dialogue with antiquity also included the later, Christian period. [...] In both cases, India had a central place. The project of converting 'the Orient', the first step in the Christianisation of the World, was - it was thought - more ambitious than the Romanization and Christianization of the Roman Empire, confined to the Mediterranean basin and adjacent territories. [...]

In fact, through metaphors, allegories, and comparisons, the efforts to classicize Portugal opened the way to (in addition to depending on) the process of exoticization and orientalization. If classicism was an identity locus that defined its interior - with its exterior vertiginously extending towards the east and the west - the identification of the difference was a way to bring it into focus and strengthen it.

The role played by the perceptions and representations of Islam was crucial in this context. In order to establish the topos that Islamic presence was an intrusion into Portuguese history - a topos that later Orientalisms would disseminate about in India, for example - it was necessary to make visible the differences, not only religious, but also political, social, and cultural. These differences justified the fact that Islam was to be expelled from the Portuguese historical memory just as Muslims were physically expelled from the kingdom. ${ }^{63}$

We can then conclude that the orientalization of the Other was mandatory, in the first European modernity, for the very construction of a Portuguese identity.

\section{The perenniality of certain values}


The principal interlocutor of these authors (their homeland), before the Enlightenment, was still 'Christendom in general, society conceived universally'; only after the Industrial Revolution, and with Romanticism, does the Camonian homeland become identified with the sociopolitical individual, 'the liberal man [...] responsible for his destiny and for the profile of that new entity, the homeland-nation' ${ }^{64}$ However, it should be noted that, until the $20^{\text {th }}$ century, 'whatever the ideological interpretation of Camões, it is not possible for anyone to dissociate his epic telling from the historical apology of a people seen as the vanguard of a faith threatened in Europe at the time [by Islam] and of an empire equally at the forefront of the Occident's commercial and military expression'. ${ }^{65}$

One can say that a certain paradigm of Respublica Christiana will be present even among the most liberal of writers. In fact, 'the vast majority of liberal Portuguese were in favor of an organic connection between the State and the Church' ${ }^{66}$ The Empire can no longer be idealized as the universal homeland of Christendom but, for many, not only should the values of the latter continue to integrate it, but their vision of the Other will continue to be constrained by religion.

Let us consider the Oriental episode 'Mogarém', included in the second tome of Jornadas ['Journeys'] (1874) by the poet Tomás Ribeiro, and imbued with the same 'Camonian titles' of a universal vocation triggered by the Discoveries: it revolves around the second siege of Diu, which took place in 1546, with all the universalizing ingredients of the perception of the Portuguese Empire in the first European modernity, through which, in the narrative, not only the Muslims, but also (and especially) the Hindus are demonized as an appeal to the lusitanization and Christianization of the native characters in the plot. What makes this account original (though not surprising, given that Ribeiro was a writer of the Portuguese Ultra-Romanticism) is the fact that the backstage and the echoes of the battle that reached Old Goa play out alongside a love story between an Indian woman, Mogarém, and D. Fernando, one of the sons of the vice-governor D. João de Castro, who would die precisely during the siege of Diu. In Ribeiro's words, 'Glory and Love would marry in the same ideal' ${ }^{67}$ This glory, that of the heroic actions of the $16^{\text {th }}$ century, is shaped by the same dialogue (from the initial phase of European expansion) of classic Antiquity with the subsequent Christian period, as can be noticed by the references to the Iliad and the Odyssey, and the almost complete protagonism of Francis Xavier, the evangelizer of Asia. This is evident in Xavier's spiritual support of the battle and of the young couple, in addition to his 
conversion of Mogarém and her family to Catholicism (all fictional, since Xavier was in the Moluccas by then). Ribeiro even establishes an intertextual connection with previous accounts of the siege of Diu, especially with the biography of D. João de Castro written by Jacinto Freire de Andrade (1597-1657), Vida de D. João de Castro, quarto viso-rei da India ['The Life of D. João de Castro, fourth Viceroy of India'], published posthumously in 1786 .

In sum, what Tomás Ribeiro's Oriental episode does, if read in the light of the liberal convictions expressed by the author throughout the Jornadas, is seek to resolve 'the pathological mismatch between the present and the past' of Portuguese hyperidentity by imprinting on the modern conscience of its generation the values of the ideals fabricated by the Portuguese Empire in the $16^{\text {th }}$ century:

The episode I am going to publish is modest; it is a sketch of oriental customs, and it occurred at a time when our missionaries, fervent soldiers of religion and the homeland, took their conquests of love to the hardened bosom of the ancient peoples of the Orient.

In each monsoon, the Portuguese galleons carried to the ports of India warriors of two kinds; rivals but not enemies: - soldiers and priests. It was a beautiful period. $[\ldots]$

You are right in many of your doctrines, but you fall, as victims of deplorable visions, into frightful exaggerations.

A new school will come to support the conquests of reason with the elevation of sentiment, because nature always triumphs in the end, and when there is no more danger of falling into the excesses of idolatries, nor of losing ourselves in the infinite wastelands of abstract cogitations, the time of the great conquests of humanity will come. ${ }^{68}$

The Orient idealized by a $19^{\text {th }}$ century author for a $16^{\text {th }}$ century episode can be read as a 'compensatory myth', in Lourenço's terms. We cannot ignore the geopolitical reality of Ribeiro's time: the British Empire had already established itself definitively. Ribeiro travelled (via the Mediterranean) to Portuguese India to assume the position of general secretary to the vice-governor at the time, Visconde de S. Januário; his journey took place under the sign of Camões, even though the poet and his companions (including the vice-governor himself) did not have 'before them the perspective of heroism'. ${ }^{69}$ Portugal was already affected, as we have seen in Lourenço's words, in its 'double identity as a non-hegemonic European people and as a people'. Ribeiro is fairly 
conscious of that: 'England is taken as the model for liberal nations: let it be, though; but it is only fair that we are not assigned an inferior position. While it proclaims liberty, we execute its precepts, practicing with conviction the dogmas of fraternity, which is its emanation as a sentiment, and its corollary as a doctrine' ${ }^{70}$ In effect, we see that Ribeiro's work confirms the colonialist myth of Portugal as described by Lourenço, that is, of an other-colonization. ${ }^{71}$

Although the generation that followed Tomás Ribeiro's would question a discourse "animated by a false ideal of old-fashioned glory, ${ }^{72}$ - which is what the poet Antero de Quental wrote about Jacinto Freire de Andrade's biography of D. João de Castro -, the Empire will always be pivotal in the relationship of intellectuals with their country. Even if, for that generation, ${ }^{73}$ it was precisely the alliance of Faith and Sword that caused the decadence of Portugal, still 'the perceived breach between the real Portugal and the dreamed and demanded Portugal becomes a mental form and is elevated to a kind of ontological dignity'. ${ }^{74}$ However, despite the efforts of that generation, the Christocentric character of Portuguese expansion would continue to dominate much of the discourse, reaching its paroxysm in the $20^{\text {th }}$ century, with the Estado Novo.

An interesting case involving the theme of the sieges of Diu is that of $O I I^{\circ}$ Cerco de Dio ['The Second Siege of Diu'] (1963), written by Arthur Lambert da Fonseca (1922-2013). It was published at a rather delicate time for the dictator Salazar, since the Portuguese had already had to leave India after Goa, Daman, and Diu had been annexed by the Indian Union (1961), and Portugal was under growing international pressure to grant independence to its other colonies (the remaining European countries with colonies in Africa, Asia, and Oceania had already initiated the process). Just like Tomás Ribeiro before him, in order to write his narrative, Fonseca relied on texts from the $16^{\text {th }}$ and $17^{\text {th }}$ centuries, written by the aforementioned Jacinto Freire de Andrade, as well as by Diogo do Couto, Faria e Sousa, Leonardo Nunes, and Gaspar Correia.

António José de Brito's introduction of the work, printed on the book flaps, exposes the workings of both a 'pathological mismatch between past and present' and a 'compensatory myth' (see Lourenço above) in Fonseca's rewriting of the second siege of Diu: 'Faced with the painful successes - or rather, failures - of the present, [Fonseca] turned to the glorious pages of our history, not with the intent of taking refuge in the past (otherwise, he would have produced a work of slow and long erudition), but to 
highlight the perenniality of certain values that deserve observation on whatever occasion, and, therefore, it is urgent to project onto the future' ${ }^{75}$

Since the end of the $19^{\text {th }}$ century, political and intellectual forces debated the best way to deal with islamicised populations within the Empire, especially in Africa, ${ }^{76}$ and, under the civilian dictatorship and due to international contingencies of the time, Portugal portrayed itself 'officially [as] a multi-continental country spread over three continents (Europe, Africa and Asia), and a multi-racial one in which all races that constituted the Portuguese nation lived in harmony' ${ }^{77}$ In contrast, Fonseca described the second siege through the already familiar hyperbolization of the Portuguese feats of arms, but also of the enemy attacks - concurring to produce a representation 'limited in their imagery, assumptions, and intentions', which is the Orientalist representation (see Said's quote above). In the following passage, notice the contrast between the identification of each Portuguese hero by name and a homogeneous, nameless mass, or otherwise identified with 'Mohamed':

They were slender pennants with entire verses from the Koran set between multicolored embroidery. They were black flags with white crescents and stars, heavy banners with black arabesque on silver, and silver on red, framing shining golden suns with the Prophet's commandments written in blue letters. The veils increasingly torn and, in the twilight of dawn, the horrific aspect of all that ocean of turbans, helmets, coats, black cloaks, burnouses, moving slowly to the sound of their lugubrious bands and the mournful choruses of their prayers imploring the aid of Mahomet, was chilling. It was horrific, uncanny, barbaric and repulsive. [...]

[...] Luís de Sousa, with his noblemen, among whom stood out D. Fernando de Castro and Diogo de Reimoso, ceaselessly delivered death left and right. D. João de Almeida and his brothers D. Francisco and D. Pedro seemed taken by a terrible madness, decimating like vengeful archangels, callous to the blows they received. Juzarcão rose up against the tower and António Paçanha did not even have time to take a breath, covered in cuts and blood. The moors, in truth, came in gusts, but their onslaught fell apart, like weak waves, before our spirit of steel and will of iron. From the high Skies, even St. Michael, the Constable of celestial regiments, was certainly in awe, watching such people in battle. ${ }^{78}$

\section{Conclusion}


I propose that Eduardo Lourenço's notion of hyperidentity can be used as a concept to study Portuguese Orientalism. In any case, from the point of view of the 'discursive perspective' (see Young on Said's work, above) that I have shown in this article, it confirms the adequacy of the conceptual and methodological framework of Orientalism to analyze the Portuguese representations of the Orient. 'Portuguese hyperidentity' allows us to understand how the Other is inserted into an imagined community, ${ }^{79}$ the possibilities of that community being assessed in terms of their relation with the empire.

As rightly noted by Manuel Cândido Pimentel, 'if the myth of Portugal is the foundation of homeland and nation, it is because, by giving cohesion to the fundamental archetypes of our culture, it is also the driving force of the Portuguese in their terrestrial journey: it proposes the knowledge of cultural identity and the rooting of motives, promoting the sense that fulfils us and inspires or should inspire both ideal and praxis $^{80}$. In the interstitial space between ideal and praxis, it is possible to recover, in Stuart Hall's words, the 'different discourses, or ways in which the West came to speak of and represent other cultures', assuming that 'the discourse of the West about the Rest was deeply implicated in practice'. ${ }^{81}$

We should also not forget that 'the Age of Exploration and Conquest' - which helped "to forge that new sense of identity that we call "the West" - "began with Portugal, after the Moors [...] had finally been expelled from the Iberian peninsula' ${ }^{82}$ The Portuguese representations of the sieges of Diu do not only evince that, in addition to being historical episodes, these events constitute a synecdoche of Portugal's own myth; they also demonstrate how a people seen as an 'enemy' could become a synecdoche of the Orient.

\footnotetext{
${ }^{1}$ Translated from Portuguese by Rui Vitorino Azevedo and revised by Hugo Cardoso. This article was written in the context of the Exploratory Research Project 'The Portuguese Representations of India: Power and Knowledge in a Peripheral Orientalism $\left(19^{\text {th }}\right.$ and $20^{\text {th }}$ centuries)', funded by Portugal's Fundação para a Ciência e a Tecnologia (IF/01452/2013).

${ }^{2}$ Edward W. Said, Orientalism: Western Conceptions of the Orient (London: Penguin, 1978), p. 17.

${ }^{3}$ Said, Orientalism, p. 12.

${ }^{4}$ Said, Orientalism, p. 7.

${ }^{5}$ Said, Orientalism, p. 7.

${ }^{6}$ Said, Orientalism, p. 20.

${ }^{7}$ Eduardo Lourenço, Do Colonialismo como Nosso Impensado (Lisbon: Gradiva, 2014), p. 277.

${ }^{8}$ Eduardo Lourenço, Nós e a Europa ou as Duas Razões (Lisbon: INCM, 1988), p. 88.

${ }^{9}$ Said, Orientalism, p. 2.

${ }^{10}$ See Said, Orientalism, p. 3 and pp. 6-7, respectively.

${ }^{11}$ The United States, which emerge as a hegemonic force after World War II, are also addressed, but as agents of a subsidiary European Orientalism.

${ }^{12}$ Said, Orientalism, p. 121.
} 
13 See, for example, Comissão Nacional para as Comemorações dos Descobrimentos Portugueses, $O$ Orientalismo em Portugal: séculos XVI-XX (Lisbon: CNCDP, 1999).

14 Ângela Barreto Xavier and Ines G. Zupanov have already contradicted this idea. According to the authors, an entire corpus of knowledge produced by the Portuguese at the beginning of the Modern Era (in fact, still moulded by a medieval vision of the world), confirms 'the interdependence of knowledge and political demands'; Ângela Barreto Xavier and Ines G. Zupanov, Catholic Orientalism - Portuguese Empire, Indian Knowledge (16th-18th centuries) (New Delhi: Oxford University Press, 2015), p. XXV.

${ }^{15}$ Robert J. C. Young, 'The Legacies of Edward W. Said in Comparative Literature Comparative', Comparative Critical Studies 7.2-3 (2010), 360.

${ }^{16}$ Said, Orientalism, p. 202.

${ }^{17}$ Said, Orientalism, p. 42.

${ }^{18}$ Said, Orientalism, p. 24.

${ }^{19}$ Said, Orientalism, p. 11.

${ }^{20}$ Eduardo Lourenço, O Labirinto da Saudade - Psicanálise Mítica do Destino Português (Lisbon:

Gradiva, 2013), pp. 17-18 and p. 46, respectively.

${ }^{21}$ Lourenço, O Labirinto da Saudade, p. 18.

${ }^{22}$ Lourenço, Do Colonialismo como Nosso Impensado, p. 276-277.

${ }^{23}$ Lourenço, Do Colonialismo como Nosso Impensado, p. 124 and p. 301, respectively.

${ }^{24}$ Lourenço, Nós e a Europa ou as Duas Razões, p. 10.

${ }^{25}$ Lourenço, Do Colonialismo como Nosso Impensado, p. 305.

${ }^{26}$ Lourenço, Do Colonialismo como Nosso Impensado, pp. 132-133.

${ }^{27}$ Lourenço, Do Colonialismo como Nosso Impensado, p. 307.

${ }^{28}$ Lourenço, Do Colonialismo como Nosso Impensado, p. 132.

${ }^{29}$ Lourenço, Do Colonialismo como Nosso Impensado, p. 129 and p. 130, respectively.

${ }^{30}$ Lourenço, Do Colonialismo como Nosso Impensado, p. 132.

${ }^{31}$ Lourenço, Do Colonialismo como Nosso Impensado, p. 301.

${ }^{32}$ To use an expression coined by Boaventura de Sousa Santos, 'Entre Próspero e Caliban: colonialismo, pós-colonialismo e inter-identidade', in Entre ser e estar - Raízes, percursos e discursos da identidade, ed. by Maria Irene Ramalho and António Sousa Ribeiro (Porto: Afrontamento, 2001), p. 26.

${ }^{33}$ Lourenço, Do Colonialismo como Nosso Impensado, pp. 302-303.

${ }^{34}$ Lourenço, O Labirinto da Saudade, p. 18.

${ }^{35}$ Stuart Hall, 'The West and the Rest: Discourse and Power', in Formations of Modernity, ed. by Stuart Hall and Bram Gieben (Cambridge: The Open University, 1992), pp. 275-320.

${ }^{36}$ Said, Orientalism, pp. 331-332.

${ }^{37}$ Rosa Maria Perez, 'Introdução', in Os Portugueses e o Oriente - história, itinerários, representações, ed. by Rosa Maria Perez (Lisbon: Dom Quixote, 2006), p. 21.

${ }^{38}$ Lourenço, Do Colonialismo como Nosso Impensado, p. 131.

39 "Truth is a thing of this world: it is produced only by virtue of multiple forms of constraint. And it induces regular effects of power. Each society has its regime of truth, its "general politics" of truth - that is, the types of discourse it accepts and makes function as true; the mechanisms and instances that enable one to distinguish true and false statements; the means by which each is sanctioned; the techniques and procedures accorded value in the acquisition of truth; the status of those who are charged with saying what counts as true". Michel Foucault, 'Truth and power', in Michel Foucault, Power/Knowledge: Selected Interviews and Other Writings 1972-1977, ed. by C. Gordon (New York: Pantheon Books, 1980), p. 131.

${ }^{40}$ Patrik Hall, 'Nationalism and historicity', Nations and Nationalisms 3.1 (1997), 3.

${ }^{41}$ Lourenço, Do Colonialismo como Nosso Impensado, p. 125.

${ }^{42}$ Lourenço, Do Colonialismo como Nosso Impensado, p. 142 and p. 153, respectively.

${ }^{43}$ Said, Orientalism, p. 2.

${ }^{44}$ Since the historical and material realities of the British and French empires were different from that of the Portuguese empire, critics easily dismiss the question of the exercise of power. See, for example, Alito Siqueira, 'Goa: do ocidentalismo ao pós-colonialismo', in Os Portugueses e o Oriente - história, itinerários, representações, ed. by Rosa Maria Perez (Lisbon: Dom Quixote, 2006), p. 151-166; Kenneth David Jackson, 'Goa e a orientalidade', in Goa Portuguesa e Pós-colonial. Literatura, Cultura e Sociedade, ed. by Everton V. Machado and Duarte D. Braga (Vila Nova de Famalicão: Húmus, 2014), p. 13-37; Eva-Maria von Kemnitz, 'Em Portugal - O Orientalismo em fragmentos', Revista de estudios internacionales mediterráneos 21 (2016), 13-25.

${ }^{45}$ Lourenço, Do Colonialismo como Nosso Impensado, pp. 139-140.

${ }^{46}$ See Luís Filipe F. R. Thomaz, De Ceuta a Timor (Lisbon: Difel, 1994), pp. 189-206. 
${ }^{47}$ João Paulo Oliveira e Costa et al., História da Expansão e do Império Português (Lisbon: Esfera dos Livros, 2014), p. 17.

${ }^{48}$ Walter Rossa, Património de Origem Portuguesa no Mundo: Arquitetura e Urbanismo (Ásia e Oceânia) (Lisbon: Fundação Calouste Gulbenkian, 2010), p. 66.

${ }^{49}$ Maria Teresa Amado, 'Diu', in Dicionário de História dos Descobrimentos Portugueses, vol. 1, ed. by Luís de Albuquerque (Lisbon: Caminho, 1994), pp. 357-358.

${ }^{50}$ Not to mention that the feats of arms are a constant in the general representations of the Portuguese Empire.

${ }^{51}$ Jorge A. Osório, ‘Em torno dos dois "De Bello Cambaico" de Damião de Góis', Máthesis 12 (2003), p. 174.

${ }^{52}$ Nuno Grancho, Diu, a social architectural and urban history, doctoral dissertation on Heritage of Portuguese Influence, Architecture and Urbanism (Coimbra: University of Coimbra, 2016), p. 89.

${ }^{53}$ Roger Lee de Jesus, O Segundo Cerco de Diu (1546) - Estudo de História Política e Militar, masters dissertation on History of the Early Modern Period (Coimbra: University of Coimbra, 2012), p. 141.

${ }^{54}$ Lourenço, Do Colonialismo como Nosso Impensado, p. 132.

${ }^{55}$ Manuel Cândido Pimentel, 'O mito de Portugal nas suas raízes culturais', in Portugal: Percursos de interculturalidade, ed. by Artur Teodoro de Matos and Mário Ferreira Lages, vol. 3 (Lisbon: ACIDI, 2008), p. 11.

${ }^{56}$ Margarida Calafate Ribeiro, Uma História de Regressos: Império, Guerra Colonial e PósColonialismo (Porto: Edições Afrontamento, 2004), p. 21.

${ }^{57}$ Luís de Camões, The Lusiads, translated from Portuguese into English by Richard Francis Burton (London: Bernard Quaritch, 1880), vol. 1., p. 61.

${ }^{58}$ Camões, The Lusiads, vol. 2, p. 386.

${ }^{59}$ See Ziauddin Sardar, Extraño Oriente: Historia de un prejuicio, translated from English into Spanish by Tomás Fernández Aúz and Beatriz Eguibar (Barcelona: Gedisa, 2004), p. 57.

${ }^{60}$ Said, Orientalism, p. 66

${ }^{61}$ Fernando Machado Silva, 'Presentación de un monstruo renascentista: Viejo Mouro', Studia Aurea 2 (2008) $<$ http://studiaaurea.com/article/view/v2-machado/15> [accessed 1 January 201].

${ }^{62}$ Hélio J. S. Alves, 'Jerónimo Corte-Real', in Dicionário de Luís de Camões, coord. by Vítor Aguiar e

Silva (Lisbon: Caminho, 2011), p. 300-301.

${ }^{63}$ Xavier and Zupanov, Catholic Orientalism, pp. 11-12.

${ }^{64}$ Lourenço, O Labirinto da Saudade, pp. 82-83.

${ }^{65}$ Lourenço, O Labirinto da Saudade, p. 121.

${ }^{66}$ Vítor Manuel Parreira Neto, 'O Liberalismo católico de Alexandre Herculano', in Alexandre Herculano

- Liberalismo e romantismo (Santarém: Escola Superior de Educação de Santarém, 1999), p. 59.

${ }^{67}$ Tomás Ribeiro, Jornadas (Coimbra: Livraria Central de José Diogo Pires, 1874), vol. 2, p. 270.

${ }^{68}$ Ribeiro, Jornadas, vol. 2, pp. 253-255.

${ }^{69}$ Ribeiro, Jornadas, vol. 1, p. 26.

${ }^{70}$ Ribeiro, Jornadas, vol. 2, pp. 243-244.

${ }^{71}$ It is interesting that the author of Jornadas collaborated with the Jornal das Colónias ['Journal of the Colonies'] under the pseudonym Tomé de Diu ['Thomas of Diu'].According to Sandra Maria Gonçalves Castelão, 'Ribeiro (Ferreira), Tomás (António)', in Dicionário do Romantismo Literário Português, coord. by Helena Carvalhão Buescu (Lisbon: Caminho, 1997), p. 479.

${ }^{72}$ Quoted in Joel Serrão, Joel, Liberalismo, Socialismo, Republicanismo: Antologia de pensamento político português (Lisbon: Livros Horizonte, 1979), p. 166.

${ }_{73}$ Writers such as Quental, Eça de Queirós, Teófilo Braga, and Oliveira Martins.

${ }_{75}^{74}$ Lourenço, O Labirinto da Saudade, p. 93.

${ }^{75}$ António José de Brito, 'O II $^{\circ}$ Cerco de Diu por Arthur Lambert da Fonseca', on the flap of: Arthur Lambert da Fonseca, $O$ II ${ }^{\circ}$ Cerco de Diu (Vila do Conde: Gládio, 1963).

${ }^{76}$ See AbdoolKarim Vakil, 'Questões Inacabadas: Colonialismo, Islão e Portugalidade', in Fantasmas $e$ Fantasias Imperiais no Imaginário Português Contemporâneo, ed. by Margarida Calafate Ribeiro and Ana Paula Ferreira (Porto: Campo das Letras, 2003), pp. 255-294.

${ }^{77}$ Fernando Tavares Pimenta, Portugal e o Século XX - Estado-Império e Descolonização (1890-1975)

(Porto: Edições Afrontamento, 2010), p. 96.

${ }^{78}$ Fonseca, $O$ II ${ }^{\circ}$ Cerco de Diu, pp. 80-81.

${ }^{79}$ See Benedict Anderson, Imagined communities: Reflections on the origin and spread of nationalism (New York: Verso, 1983).

${ }^{80}$ Manuel Cândido Pimentel, 'O mito de Portugal nas suas raízes culturais', p. 34.

${ }^{81}$ Hall, 'The West and the Rest', p. 279 and p. 291, respectively. 
${ }^{82}$ Hall, 'The West and the Rest', p. 197 and p. 191, respectively. 